DOI 10.15290/cnisk.2021.02.11.11

MAGDALENA GASSOWSKA

https://orcid.org/0000-0002-2781-0797

Uniwersytet w Białymstoku

\title{
VI Spotkanie Członków Zespołu \\ i Współpracowników Ośrodka Badań \\ Historii Kobiet: Dziennikarki, publicystki, kobiety piszące. Twórczynie przekazu źródłowego o dziejach kobiet, Białystok 17 kwietnia 2021 r. - warsztaty ${ }^{1}$
}

W dniu 17 kwietnia 2021 r. w siedzibie Wojewódzkiego Urzędu Ochrony Zabytków w Białymstoku odbyły się kolejne cykliczne warsztaty, których tematem przewodnim były dziennikarki, publicystki, kobiety piszące oraz twórczynie przekazu źródłowego o dziejach kobiet zorganizowane przez Ośrodek Badań Historii Kobiet Instytutu Studiów Kobiecych przy współpracy Pracowni Historii Kobiet w Katedrze Historii Kultury Uniwersytetu w Białymstoku. W spotkaniu, które $z$ przyczyn sanitarnych i epidemiologicznych odbyło się częśsiowo zdalnie, wzięli udział naukowcy i doktoranci $z$ Uniwersytetu w Białymstoku, UMCS w Lublinie czy UJK w Kielcach. W warsztatach brali udział, poza szerokim gronem historyków, także pra-

Publikacja przygotowana/finansowana w ramach programu Ministra Nauki i Szkolnictwa Wyższego pod nazwą DIALOG w latach 2019-2021. Jest wynikiem udziału w projekcie badawczym pt. „Ośrodek badań historii kobiet”, nr 0016/DLG/2019/10. 
soznawcy, medioznawcy i politologowie, co sprawiło, że na poruszane zagadnienia można było spojrzeć $z$ wielu perspektyw.

Obrady zainaugurowała prof. dr hab. Małgorzata Dajnowicz, która po przywitaniu obecnych gości wyjaśniła cele niniejszego spotkania. Podczas konferencji przeważały referaty dotyczace historii XIX i XX w., a duża część wystapień poświęcona została kwestiom biograficznym. Jako pierwsza referat dotyczacy Motywu matki i macierzyństwa $w$ twórczości publicystek prasy dla kobiet $w$ Polsce międzywojennej wygłosiła prof. Ewa Maj, która starała się obalić panujący mit kobiety-matki oraz zauważyła, że kobiecość to nie tylko macierzyństwo. Kolejny referat autorstwa prof. Jolanty Chwastyk-Kowalczyk przybliżył uczestnikom postać niezwykłej publicystki, dziennikarki, filantropki i prezesa Związku Pisarzy Polskich na Obczyźnie Reginy Wasiak-Taylor. Jako następna wystapiła mgr Justyna Zajko-Czochańska, prezentując niewielka część swojej rozprawy doktorskiej, a mianowicie przedstawiła referat pt. Redaktorki i dziennikarki „Przyjaciótki” w latach 1948-1975. Biografię Anna Szymańska-Kwiatkowska - redaktor naczelna „Kobiety i Życia” w latach 1986-1990 zaprezentowała dr Anna Szwed-Walczak - pracownik naukowy UMCS $\mathrm{w}$ Lublinie, natomiast pochodzacy $\mathrm{z}$ tego samego ośrodka naukowego dr Łukasz Jędrzejski zają się Polska Kroniką Filmową w latach 1949-1967 oraz jej twórczynią Heleną Lemańską. Polska Kronika Filmowa stała się także inspiracją dla mgr Justyny Granatowskiej i jej referatu Wizerunek kobiety $w$ materiałach Polskiej Kroniki Filmowej w latach 1949-1952, w trakcie którego zaprezentowała często propagandowe fotografie kobiet $z$ tamtego okresu.

Drugą część spotkania zapoczątkowało wystapienie Marii Bauchrowicz-Tockiej pt. Zarzad Główny Ligi Kobiet - geneza powstania $i$ działalność $w$ latach 1945-1982. Natomiast wybrane, niezwykle barwne sylwetki popularyzatorek programu Ligi Kobiet, m.in. Ireny Sztachelskiej, Eugenii Róży Pragierowej, Eugenii Kempary czy Jadwigi Biedrzyckiej zaprezentowała prof. Małgorzata Dajnowicz.

Podczas konferencji można było przyjrzeć się historii kobiet w różnych perspektywach czasowych, czego dowodem sa dwa ostatnie referaty wygłoszone tamtego dnia. Profesor Robert Suski w ciekawym wystapieniu przedstawił postać cesarzowej Zenobii. Prelegent próbował odpowiedzieć na pytanie, dlaczego autor Historia Augusta przypisał Zenobii autorstwo prac historycznych. Ostatni tego dnia referat dotyczył tematyki małżeństwa, romansów i ety- 
kiety towarzyskiej - mgr Magdalena Gąsowska w swoim wystapieniu Jane Austen - duma czy uprzedzenie? starała się odpowiedzieć na to pytanie oraz przedstawiła losy pisarki.

Warsztaty Ośrodka Badań Historii Kobiet były niezwykle owocne i interesujące. Przedstawiano w trakcie ich przebiegu wiele not biograficznych znanych i mniej znanych kobiet - bohaterek historii, a obecność prelegentów i prelegentek zajmujących się tak wieloma dziedzinami nauki zapewniła uczestnikom możliwość zapoznania się $z$ zagadnieniami dotyczącymi kobiet $z$ wielu perspektyw. 